\title{
Association of neutrophil-to-lymphocyte ratio and microalbuminuria in patients with normal eGFR
}

\author{
AYSUN AYBAL KUTLUGUN ${ }^{1}$, FATMA AYERDEN EBINC ${ }^{1}$, MUJGAN TEK OZTURK ${ }^{2}$, FATMA KAPLAN EFE ${ }^{3}$, \\ IBRAHIM KARADAG ${ }^{3}$, MURAT ESER $^{3}$, OKTAY UNSAL ${ }^{3}$, SERDAR KARAKAYA ${ }^{3}$ \\ ${ }^{1}$ Department of Nephrology, Keçioren Education and Research Hospital, Ankara, Turkey \\ ${ }^{2}$ Department of Cardiology, Keçioren Education and Research Hospital, Ankara, Turkey \\ ${ }^{3}$ Department of Internal Medicine, Keçioren Education and Research Hospital, Ankara, Turkey
}

\begin{abstract}
Aims. The aim of this study was to evaluate the association between neutrophil-to-lymphocyte ratio (NLR), platelet-to-lymphocyte ratio (PLR) and microalbuminuria in patients with normal estimated glomerular filtration rate (eGFR).

Methods. 174 patients who had eGFR $\geq 60 \mathrm{~mL} / \mathrm{min} / 1.73 \mathrm{~m}^{2}$ were studied. Patients were divided into two groups according to the urinary albumin excretion as microalbuminuric group $(\mathrm{n}=$ $105)$ and normoalbuminuric group $(n=69)$. NLR and PLR levels were calculated.

Results. NLR was significantly higher $(p<0.05)$ in microalbuminuric patients $(1.91 \pm 0.70)$ compared with normoalbuminuric patients $(1.63 \pm 0.53)$. A positive correlation was found between urine albumin excretion and NLR in the whole study group $(r=0.214, p<0.005)$.

Conclusions. Higher NLR levels were found in microalbuminuric patients with normal eGFR. Also a significant positive correlation was observed between albuminuria and NLR.
\end{abstract}

Key words: Microalbuminuria, neutrophil-to-lymphocyte ratio, platelet-to-lymphocyte ratio.

\section{INTRODUCTION}

Neutrophil-to-lymphocyte ratio (NLR) and platelet-to-lymphocyte ratio (PLR) have been found to be available novel markers to determine inflammation in many conditions such as malignancies and cardiac disorders [1-5]. NLR and PLR are inexpensive and measured easily. A small number of studies aimed to investigate relationship proteinuria and NLR or PLR in diabetic patients and they found that especially NLR levels were higher in albuminuric diabetic patients [6-10]. Also a positive correlation was found between NLR and albuminuria $[6,8,10]$.

Microalbuminuria is accepted as an independent risk factor for cardiovascular events and worsening renal function [11-14]. Also it is a marker of endothelial dysfunction [15]. The prevalance of microalbuminuria in diabetic and hypertensive patients has been reported as high as $28.8 \%$ and $16 \%$ respectively. In healthy population, the prevalance of microalbuminuria was found to be $5.1 \%$ [16].

The current study aimed to determine whether there is any relationship between albuminuria and
NLR or PLR levels in patients with normal estimated glomerular filtration rate (eGFR).

\section{MATERIALS AND METHODS}

The patients attending outpatient clinic with any cause and who had a spot urine albumin measurement in a 6-month period from September 2015 to February 2016 were retrospectively investigated. Patients who had eGFR less than $60 \mathrm{~mL} / \mathrm{min} / 1.73 \mathrm{~m}^{2}$ and had a spot urine albumin-creatinine ratio (ACR) greater than $300 \mathrm{mg} / \mathrm{g}$ were excluded from the study. One hundred and seventy four adult patients were included in the study. The study protocol was approved by the ethics committee of the Keçiören Education and Research Hospital.

Patients' demographic and laboratory data (age, gender, history of diabetes mellitus, history of hypertension, number of antihypertensive medications, serum creatinine, serum uric acid, total white blood cell count, absolute neutrophil, lymphocyte and platelet counts) were obtained from their medical records. The estimated glomerular filtration rate was calculated by 4 -variable MDRD equation des- 
cribed by the National Kidney Foundation as follows [17]: GFR $\left(\mathrm{mL} / \mathrm{min} / 1.73 \mathrm{~m}^{2}\right)=175 \times\left(\mathrm{S}_{\mathrm{cr}}\right)^{-1.154} \times$ $(\text { Age })^{-0.203} \times(0.742$ if female $) \times(1.212$ if African American). Urinary albumin excretion was determined by spot urine ACR. NLR and PLR levels were calculated from the same complete blood counts with automated differential counts of patients.

A diagnosis of diabetes mellitus was considered as taking antidiabetic drugs or having a hemoglobin A1C of $6.5 \%$ and above. Hypertension was defined as having systolic blood pressure > $140 \mathrm{mmHg}$ or a diastolic blood pressure $>90 \mathrm{mmHg}$ as an average of at least two blood pressure readings or taking hypertension medication.

Patients were divided into two groups according to the urinary albumin excretion. Normoalbuminuria was defined as an ACR below $30 \mathrm{mg} / \mathrm{g}$ and microalbuminuria was defined as an ACR between 30-300 mg/g.

The SPSS program version 15 (SPSS Inc., Chicago, IL, USA) was used for analysis. Whether the distribution of NLR and PLR was normal determined using the Shapiro-Wilk test and nonparametric tests were used because these data were non-normally distributed. Continuous and categorical variables were expressed as mean \pm standard deviation and percentages, respectively. Normoalbuminuric and microalbuminuric groups were compared by the Mann Whitney-U test. Comparisons of categorical variables were made by using the Chi-square test. Spearman's correlation coefficient was used to assess the associations between variables. A p value less than 0.05 was considered significant.

\section{RESULTS}

There were no significant differences in demografic and laboratory data between microalbuminuric and normoalbuminuric patients (Table 1). Mean urine albumin levels were $10.66 \pm 6.91 \mu \mathrm{g} / \mathrm{mg}$ and $107.06 \pm 79.11 \mu \mathrm{g} / \mathrm{mg}$ in normoalbuminuric and microalbuminuric group respectively. $60.9 \%$ of the normoalbuminuric group and $70.5 \%$ of the microalbuminuric group had diabetes mellitus. The prevalances of hypertension in the two groups were similar $(52.2 \%$ vs. $48.6 \%, \mathrm{p}=0.757)$.

NLR was significantly higher in microalbuminuric patients compared with normoalbuminuric patients $(1.91 \pm 0.70 v s .1 .63 \pm 0.53, \mathrm{p}=0.016)$ (Figure 1). There was a positive correlation between the urine albumin level and NLR in the whole study group $(r=0.214, p<0.005)$. In non-diabetic patients there was a significant positive correlation between NLR and albuminuria $(r=0.324, p=0.013)$.

There was no significant difference in PLR levels between the two groups $(102.59 \pm 29.44 v s$. $105.88 \pm 38.87, \mathrm{p}=0.884$ ) (Figure 2). There was not any correlation between the urine albumin level and PLR in the whole study group $(\mathrm{r}=0.108, \mathrm{p}<$ 0.005). There was a strong positive correlation between NLR and PLR in the whole study group $(\mathrm{r}=0.498, \mathrm{p}<0.001)$.

Table 1

Demographic data and laboratory parameters in normoalbuminuric and microalbuminuric patients

\begin{tabular}{|l|c|c|c|}
\hline & $\begin{array}{c}\text { Normoalbuminuric group } \\
(\mathbf{n = 6 9 )}\end{array}$ & $\begin{array}{c}\text { Microalbuminuric group } \\
(\mathbf{n}=\mathbf{1 0 5})\end{array}$ & p-value \\
\hline Sex $($ male/female) & $19 / 50$ & $41 / 64$ & 0.143 \\
\hline Age (years) & $53.48 \pm 12.54$ & $52.92 \pm 12.74$ & 0.941 \\
\hline Diabetes mellitus $(\%)$ & 60.9 & 70.5 & 0.194 \\
\hline Hypertension $(\%)$ & 52.2 & 48.6 & 0.757 \\
\hline Serum creatinine $(\mathrm{mg} / \mathrm{dL})$ & $0.79 \pm 0.13$ & $0.84 \pm 0.16$ & 0.059 \\
\hline Glomerular filtration rate $(\mathrm{mL} / \mathrm{min})$ & $91.5 \pm 17.9$ & $89.3 \pm 17.9$ & 0.457 \\
\hline Albuminuria $(\mu \mathrm{g} / \mathrm{mg})$ & $10.66 \pm 6.91$ & $107.06 \pm 79.11$ & $<\mathbf{0 . 0 0 1}$ \\
\hline Serum uric acid $(\mathrm{mg} / \mathrm{dL})$ & $5.33 \pm 1.13$ & $5.38 \pm 1.50$ & 0.934 \\
\hline WBC $\left(* 10^{3} / \mathrm{mm}^{3}\right)$ & $7.57 \pm 1.69$ & $7.94 \pm 1.85$ & 0.244 \\
\hline Neutrophil $\left(* 10^{3} / \mathrm{mm}^{3}\right)$ & $4,16 \pm 1,23$ & $4.61 \pm 1.35$ & 0.060 \\
\hline Lymphocyte $\left(* 10^{3} / \mathrm{mm}^{3}\right)$ & $2.67 \pm 0.69$ & $2.57 \pm 0.78$ & 0.310 \\
\hline Platelet $\left(* 10^{6} / \mathrm{mm}^{3}\right)$ & $260 \pm 60$ & $254 \pm 62$ & 0.211 \\
\hline Neutrophil-to-lymphocyte ratio & $1.63 \pm 0.53$ & $1.91 \pm 0.70$ & $\mathbf{0 . 0 1 6}$ \\
\hline Platelet-to-lymphocyte ratio & $102.59 \pm 29.44$ & $105.88 \pm 38.87$ & 0.884 \\
\hline
\end{tabular}




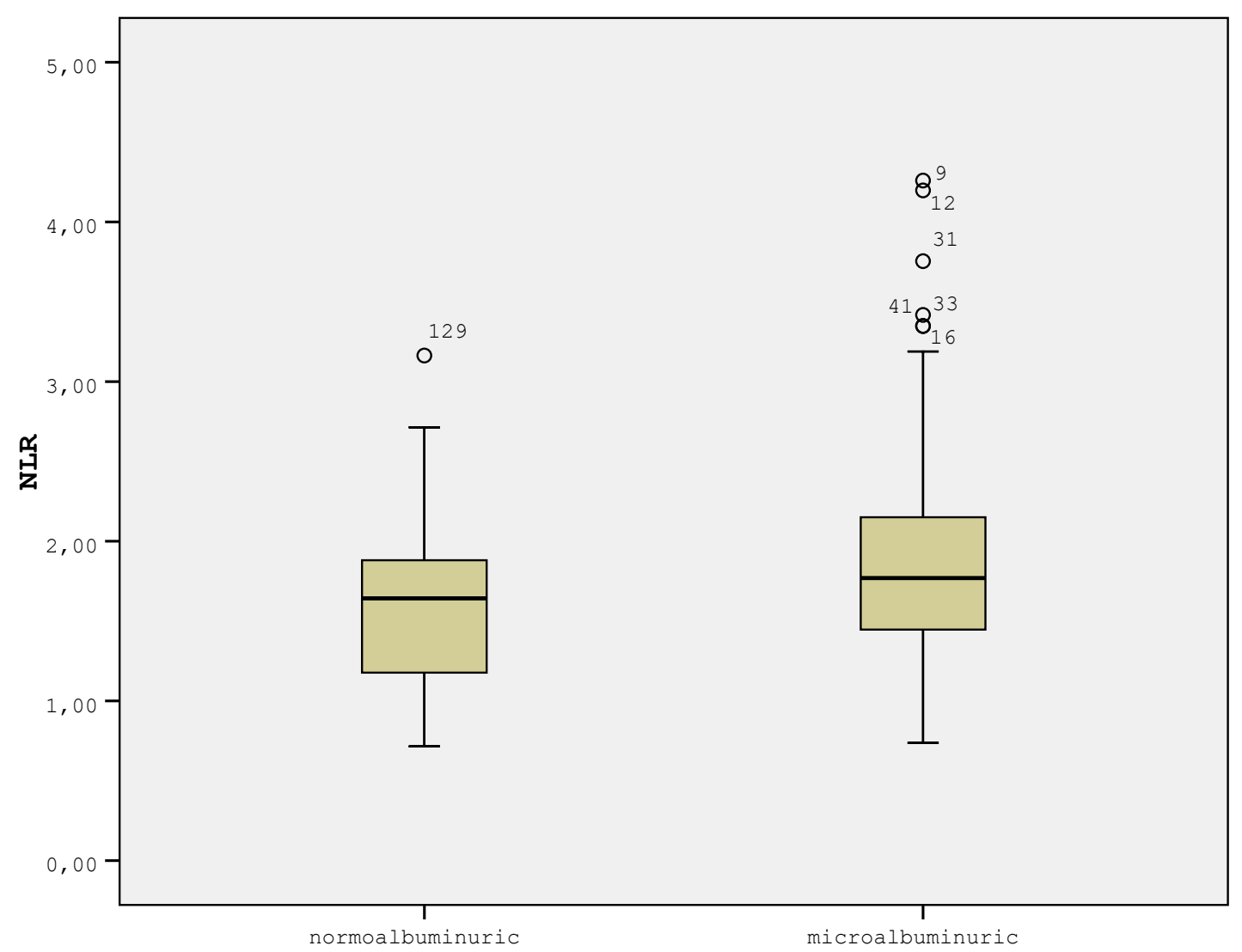

Figure 1. NLR in normoalbuminuric and microalbuminuric patients.

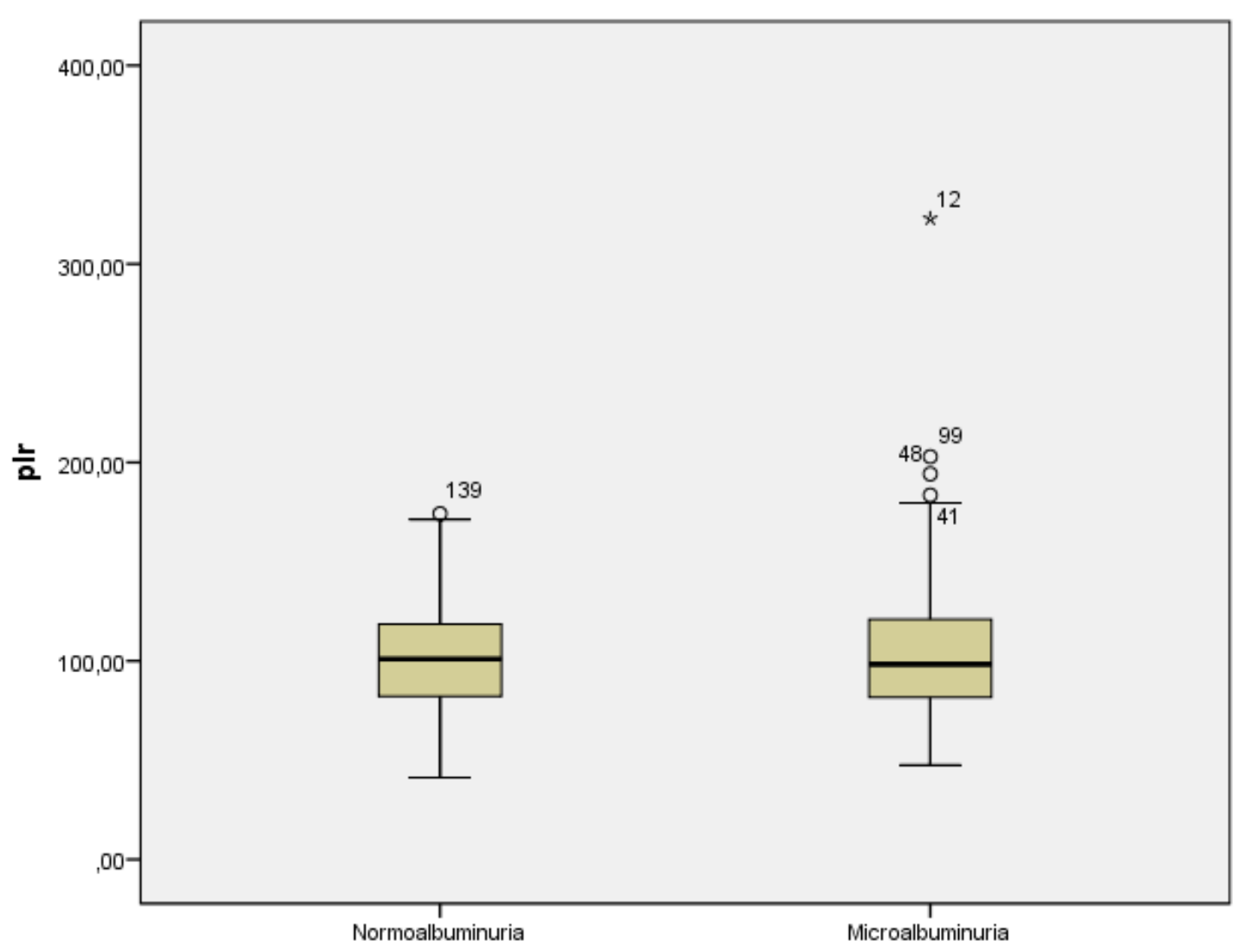

Figure 2. PLR in normoalbuminuric and microalbuminuric patients. 


\section{DISCUSSION}

In this study we demonstrated that NLR levels were higher in microalbuminuric patients than in normoalbuminuric patients. In addition, NLR levels were significantly correlated with urinary albumin excretion in all study group.

In recent years, it has been demonstrated by clinical studies that NLR determines inflammation in various conditions such as malignancies and cardiovascular disorders [1-5]. NLR can cheaply be calculated as the ratio of neutrophils to lymphocytes from a complete blood count test which is a part of routine health examination. Association between elevated NLR levels and reduced FMD that is a widely used method to evaluate endothelial function has been found in a study by Yalcin et al. [5]. Additionally, NLR has been shown to have a predictive value for cardiovascular risk and worsening renal function in diabetic patients and CKD patients $[5,7,9,18]$.

Microalbuminuria is defined as urinary albumin excretion between 30 and $300 \mathrm{mg} /$ day [19]. The presence of microalbuminuria is a marker of vascular damage and endothelial dysfunction, so it is the earliest sign of renal disease in many cases $[15,20,21]$. Microalbuminuria was found to be a predictor of cardiovascular events and worsening renal function [11-14]. An association between increased albuminuria even in the normal range and increased risk for cardiovascular events has been determined [15, 22]. Kidney Disease: Improving Global Outcomes (KDIGO) guidelines recommend use of the urine albumin to creatinine ratio in spot urine samples to detect albuminuria [23]. In the present study we assessed albuminuria with spot urine albumin to creatinine ratio.

Akbas et al. [6] investigated NLR and PLR values in 200 patients with DM in a cross-sectional study after they showed that these parameters were higher in albuminuric diabetic patients than in normoalbuminuric ones. They also found a positive correlation between albuminuria and NLR or PLR. Despite the similar findings about NLR levels and albuminuria in our study, we failed to show any relationship between PLR and albuminuria. A significant correlation between NLR and albuminuria measured via a 24-hour urine collection was found in newly diagnosed diabetic patients [10]. Moreover, a predictive effect of NLR for albuminuria in diabetic patients was reported [9]. In the present study, we included all patients who had a spot urine albumine-to-creatinine ratio test with or without diabetes mellitus. So, about 30 percent of microalbuminuric patients were not diabetic. Consistent with the findings from studies that included only patients with diabetes mellitus, we found that NLR was higher in all microalbuminuric patients with or without diabetes mellitus [6-10].

In a study that included patients with stage 3-4 chronic kidney disease (CKD) and healthy controls, NLR levels were the highest in proteinuric CKD patients and a significant correlation was detected between proteinuria and NLR in CKD patients [24]. Also, a higher prevalence of chronic kidney disease in the group with NLR $>3$ than in the low NLR group was reported [25]. Patients who had eGFR greater than $60 \mathrm{~mL} / \mathrm{min} / 1.73 \mathrm{~m}^{2}$ were included in our study and NLR was higher in microalbuminuric goup. Some studies showed that NLR levels were higher in patients with early-stage diabetic nephropathy than in patients without diabetic nephropathy $[8,9]$. Also, NLR was found as a predictor of progression of renal dysfunction assessed by the decrease in GFR in diabetic patients [7].

The limitations of this cross-sectional study were small sample size and retrospective nature that did not allow to investigate other inflamation markers such as CRP. Another limitation of this study is the lack of investigation of diseases with microinflammation, the lack of adequate data on drugs affecting NLR and the lack of smoking history. Proteinuria-reducing effects are well known regardless of the antihypertensive effect of renin-angiotensinaldosterone system (RAAS) inhibitors. However, the relationship between RAAS inhibitors and NLR was not assessed in this study because patients' RAAS inhibitor use was not retrospectively determined adequately.

In conclusion, higher NLR levels were found in microalbuminuric patients with eGFR $\geq 60 \mathrm{~mL} / \mathrm{dk} /$ $1.73 \mathrm{~m}^{2}$ in this study. So easy measurement of NLR can help to detect patients with microalbuminuria and may be a marker of early stages of kidney injury in patients with risk factors for renal involvement.

Introducere. Scopul studiului a fost de a evalua asocierea dintre raportul neutrofile-limfocite (NLR), raportul plachete-limfocite (PLR) şi microalbuminurie la pacienţii cu filtrare glomerulară normală (eGFR). 
Metode. 174 de pacienţi cu eGFR $\geq 60 \mathrm{ml} / \mathrm{min} / 1.73 \mathrm{~m}^{2}$ au fost studiaţi. Pacienţii au fost împărţiţi în două grupuri după excreţia albuminei ca microalbuminurici $(n=105)$ şi normoalbuminurici $(n=69)$. Au fost calculate NLR şi PLR.

Rezultate. NLR a fost semnificativ mai mare $(p<0.05)$ la pacienţii microalbuminurici $(1.91 \pm 0.70)$ comparativ cu pacienţii normoalbuminurici $(1.63 \pm$ 0.53). S-a observat o corelaţie pozitivă între excreţia albuminei şi NLR în tot grupul de studiu $(r=0.214, p<0.005)$.

Concluzii. Valori mai mari ale NLR au fost observate la pacienţii microalbuminurici comparativ cu pacienţii normoalbuminurici. A fost găsită o asociere pozitivă între albuminurie şi NLR.

Correspondence to: Dr. Aysun Aybal Kutlugün, Department of Nephrology,

Keçioren Education and Research Hospital, Ankara, Turkey

Tel: 00-90-5065031271

E-mail: draysunaybal@yahoo.com

\section{REFERENCES}

1. RAUNGKAEWMANEE S, TANGJITGAMOL S, MANUSIRIVITHAYA S, SRİAIIPRACHAROEN S, THAVARAMARA T. Platelet to lymphocyte ratio as a prognostic factor for epithelial ovarian cancer. J Gynecol Oncol.2012; 23:265-273.

2. JUNG MR, PARK YK, JEONG O, SEON JW, RYU SY, KIM DY, et al. Elevated preoperative neutrophil to lymphocyte ratio predicts poor survival following resection in late stage gastric cancer. J Surg Oncol. 2011; 104(5):504-10.

3. KAYA A, KURT M, TANBOGA IH, ISIK T, GUNAYDIN ZY, KAYA Y, et al. Relation of neutrophil to lymphocyte ratio with the presence and severity of stable coronary artery disease. Clin Appl Thromb Hemost. 2013; 20:473-7.

4. ERGELEN M, UYAREL H, ALTAY S, KUL S, AYHAN E, ISIK T, et al. Predictive value of elevated neutrophil to lymphocyte ratio in patients undergoing primary angioplasty for ST-Segment elevation myocardial infarction. Clin Appl Thromb Hemost. 2014; 20:427-32.

5. SOLAK Y, YİLMAZ MI, SONMEZ A, SAGLAM M, CAKİR E, UNAL HU, et al. Neutrophil to lymphocyte ratio independently predicts cardiovascular events in patients with chronic kidney disease. Clin Exp Nephrol. 2013; 17(4):532-40.

6. AKBAS EM, DEMIRTAS L, OZCİCEK A, TIMMUROGLU A, BAKİRCI EM, HAMUR H, et al. Association of epicardial adipose tissue, neutrophil-to-lymphocyte ratio and platelet-to-lymphocyte ratio with diabetic nephropathy. Int J Clin Exp Med. 2014; 7(7):1794-801.

7. AZAB B, DAOUD J, NAEEM FB, NASR R, ROSS J, GHIMIRE P, et al. Neutrophil-to-lymphocyte ratio as a predictor of worsening renal function in diabetic patients (3-year follow-up study). Ren Fail. 2012; 34:571-6.

8. CIRAY H, AKSOY AH, ULU N, CIZMECIOGLU A, GAİPOV A, SOLAK Y. Nephropathy, but not Angiographically Proven Retinopathy, is Associated with Neutrophil to Lymphocyte Ratio in Patients with Type 2 Diabetes. Exp Clin Endocrinol Diabetes. 2015; 123(5):267-71

9. HUANG W, HUANG J, LIU Q, LIN F, HE Z, ZENG Z, HE L. Neutrophil-lymphocyte ratio is a reliable predictive marker for early-stage diabetic nephropathy. Clin Endocrinol (Oxf). 2015; 82(2):229-33.

10. AFSAR B. The relationship between neutrophil lymphocyte ratio with urinary protein and albumin excretion in newly diagnosed patients with type 2 diabetes. Am J Med Sci. 2014; 347(3):217-20.

11. WANG Y, YUAN A, YU C. Correlation between microalbuminuria and cardiovascular events. Int J Clin Exp Med. 2013; 6(10):973-8.

12. PÖSS J, UKENA C, MAHFOUD F, GENSCH C, WERNER C, THOENES M, et al. Physical activity is inversely associated with microalbuminuria in hypertensive patients at high cardiovascular risk: data from I-SEARCH. Eur J Prev Cardiol. 2012; 19:1066-73.

13. HILLEGE HL, JANSSEN WM, BAK AA, DİERCKS GF, GROBBEE DE, CRIJNS HJ, et al. Microalbuminuria is common, also in a nondiabetic, nonhypertensive population, and an independent indicator of cardiovascular risk factors and cardiovascular morbidity. J Intern Med. 2001; 249:519-26.

14. KOROSHI A. Microalbuminuria, is it so important? Hippokratia. 2007; 3:105-7.

15. WRONE EM, CARNETHON MR, PANALIAPPAN LP, et al. Association of dietary protein intake and microalbuminuria in healthy adults: Third National Health and Nutrition Examination Survey. Am J Kid Dis. 2003; 41:580-587.

16. JONES CA, FRANCIS ME, EBERHARDT MS, CHAVERS B, CORESH J, ENGELGAU M, et al. Microalbuminuria in the US population: third National Health and Nutrition Examination Survey. Am J Kidney Dis. 2002;39:445-59.

17. LEVEY AS, BOSCH JP, LEWIS JB, et al. A more accurate method to estimate glomerular filtration rate from serum creatinine: a new prediction equation. Modification of diet in Renal Disease Study Group (PDF). Ann Intern Med. 1999; 130:461. 
18. AZAB B, ZAHER M, WEISERBS KF, TORBEY E, LACOSSİERE K, GADDAM S, et al. Usefulness of neutrophil to lymphocyte ratio in predicting short- and long-term mortality after non-ST-elevation myocardial infarction. Am J Cardiol. 2010; 106:470-6.

19. NATIONAL KIDNEY FOUNDATION KIDNEY DISSEASE OUTCOMES QUALITY INITIATIVE. CLINICAL PRACTICE GUIDELINES FOR CHRONIC KIDNEY DİSEASE; Evaluation, Classification and Stratification. Am J Kidney Disease. 2002; 39(Suppl 1):S1-S264.

20. IMAMOVIC G, TRNACEVIC S, TABAKOVIC M, et al. Microalbuminuria. The new marker for Balkan Endemic Nephropathy. BANTAO Journal. 2006; 4:58-59.

21. MOGENSEN CE, CHRİSTENSEN CK. Predicting diabetic nephropathy in insulin dependent patients. New Eng J Med. 1984; 311:89-93.

22. RUGGENENTİ P, REMUZZİ G. Time to abandon microalbuminuria. Kidney Int. 2006;70:1214-1222.

23. LEVEY AS, DE JONG PE, CORESH J, et al. The definition, classification, and prognosis of chronic kidney disease: a KDIGO Controversies Conference report. Kidney Int. 2011; 80:17-28.

24. BINNETOĞLU E, ŞENGÜL E, HALHALLI G, DİNDAR S, ŞEN H. Is neutrophil lymphocyte ratio an indicator for proteinuria in chronic kidney disease? J Clin Lab Anal. 2014; 28(6):487-92.

25. ERTURK M, CAKMAK HA, SURGIT O, CELIK O, AKSU HU, AKGUL O, et al. Predictive value of elevated neutrophil to lymphocyte ratio for long-term cardiovascular mortality in peripheral arterial occlusive disease. J Cardiol. 2014; 64(5):371-6.

Received July 27, 2017 